\title{
EHMTI-0081. Use of rotigotine in chronic cluster headache
}

\author{
L Savi , C Condello, L Pinessi \\ From 4th European Headache and Migraine Trust International Congress: EHMTIC 2014 \\ Copenhagen, Denmark. 18-21 September 2014
}

\section{Background}

Chronic Cluster Headache $(\mathrm{CCH})$ is an infrequent form of Cluster Headache, defined by the absence of remission periods. Medical treatments are few, sometimes ineffective and poorly tolerated. Rotigotine was recently reported as useful in a single patient with $\mathrm{CCH}$.

\section{Aim}

Reporting the results observed using rotigotine in four cases with $\mathrm{CCH}$.

\section{Cases report}

All patients received a diagnosis of $\mathrm{CCH}$ according to ICHD-3 Beta. Brain imaging and neurological examination were normal. Patients were 61, 67, 49 and 45 respectively. Verapamil, carbolithium and steroids were used unsuccessfully.

Case 1: he had tried Gammacore and pregabalin, too, ineffectively. Transdermal rotigotine was started at the dose of $2 \mathrm{mg} /$ die. After a few days, only scarce, minor attacks persisted, and were stopped by titrating posology to $4 \mathrm{mg} /$ die.

Case 2: rotigotine was titrated up to $6 \mathrm{mg} / \mathrm{die}$, without any beneficial effect, and after a month it was discontinuated.

Case 3 and 4: titration proceded to $4 \mathrm{mg} / \mathrm{die}$, for persistence of minor attacks with lower doses. Lasting remission has been observed since.

No adverse event has been reported by the patients.

\section{Conclusions}

Rotigotine is a non-ergoline D3-like receptor agonist. Its availability in the transdermal form and its safety profile make it well accepted by patients. The four subjects whose cases we reported did not show any adverse event. Three

Headache Center, Città della salute e della scienza, Torino, Italy of them showed initial but definite benefit from this therapy and are currently free from pain and under follow-up. We think that rotigotine should be considered in the management of $\mathrm{CCH}$ unresponsive to common treatment.

No conflict of interest.

Published: 18 September 2014

doi:10.1186/1129-2377-15-S1-C12

Cite this article as: Savi et al:: EHMTI-0081. Use of rotigotine in chronic cluster headache. The Journal of Headache and Pain 2014 15(Suppl 1):C12.

\section{SpringerOpen $^{\odot}$}

(c) 2014 Savi et al; licensee Springer. This is an Open Access article distributed under the terms of the Creative Commons Attribution License (http://creativecommons.org/licenses/by/2.0), which permits unrestricted use, distribution, and reproduction in any medium, provided the original work is properly cited.
Submit your manuscript to a SpringerOpen ${ }^{\circ}$ journal and benefit from:

- Convenient online submission

- Rigorous peer review

- Immediate publication on acceptance

- Open access: articles freely available online

- High visibility within the field

Retaining the copyright to your article

Submit your next manuscript at $>$ springeropen.com 